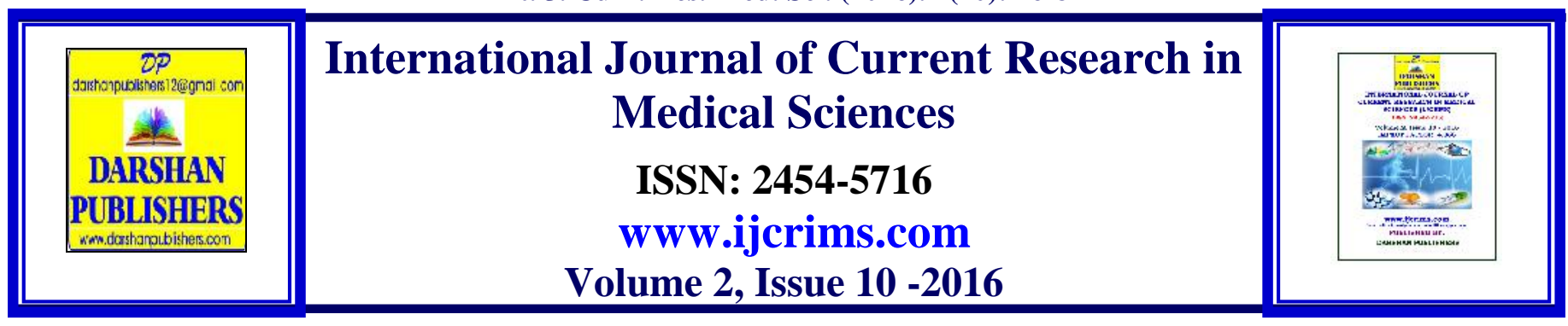

\title{
In vitro anti-inflammatory activity and tissue culture studies on Tinospora cordifolia
}

\author{
Maanhvizhi. $\mathbf{E}^{1}$ and Revathi. $\mathbf{K}^{2 *}$ \\ ${ }^{1}$ Research Scholar, ${ }^{2 *}$ Associate Professor and Head, Department of Zoology, Ethiraj College for Women, \\ Chennai-8, Tamilnadu, India. \\ *Corresponding author: reva63@ rediffmail.com
}

\begin{abstract}
The present study deals with the in vitro anti-inflammatory in methanolic extracts of in vivo (leaf and stem) and in vitro (callus) plant parts of Tinospora cordifolia (Acanthaceae) is a medicinal plant of immense therapeutic value. The present work is based on developing a protocol for the callus induction in T. cordifolia from stem and leaf explants. The highest rate of callus (70.82\%) was observed on MS medium fortified with $1.5 \mathrm{mg} / \mathrm{L} \mathrm{2,} \mathrm{4-D} \mathrm{and} \mathrm{0.3}$ $\mathrm{mg} / \mathrm{L}$ BAP. The methanolic extracts of all plant parts exhibited remarkable anti-inflammatory activity action. The maximum amount of membrane stabilization was found in stem callus $(78.15 \%$ at a dose of $100 \mathrm{~g} / \mathrm{ml})$ as compare to other plant and callus parts tested. Therefore, our studies support the isolation and the use of active constituents from in vivo and in vitro plant parts of $T$. cordifolia in treating inflammations.
\end{abstract}

Keywords: Tinospora cordifolia, callus, in vitro anti-inflammatory, HRBC membrane stabilization.

\section{Introduction}

Inflammation is a pathophysiological response of living tissue to injury that leads to local accumulation of plasmatic fluid and blood cells. Although it is a defense mechanism that helps body to protect it-self against infection, burns, toxic chemicals, allergens or other noxious stimuli, the complex events and mediators involved in the inflammatory reaction can induce, maintain or aggravate many diseases (Sosa et al., 2002).

All the steroidal and non-steroidal antiinflammatory drugs (NSAIDs) which have been used since the introduction of acetyl salicylic acid are heterogeneous group of compounds which share many pharmacological properties and side effects, are probably polycompetent in that they are able to modulate more than one mediator or cellular event concerned with the inflammatory response (Whitehouse, 1974). For this reason, in recent time, more interest is shown in alternative and natural drugs for treatment of various diseases, but there is lack of scientific evidence (David et al., 2014).

The resurgence of public interest in plant based medicine coupled with rapid expansion of pharmaceutical industries have necessitated an increased demand for medicinal plants, leading to over-exploitation that threatens the survival of 
Int. J. Curr. Res. Med. Sci. (2016). 2(10): 76-81

many rare species. Also, many medicinal plant species are disappearing at an alarming rate due to rapid agricultural and urban development, uncontrolled deforestation and indiscriminate collection. Plant tissue culture technology holds great promise for micropropagation, conservation, and enhancement of the natural levels of valuable secondary plant products and to meet pharmaceutical demands and reduce the in situ harvesting of natural forest resources (Yogananth et al., 2012).

The herb Tinospora cordifolia (Menispermaceae) is commonly known as Guduchi in India. It has a long history of use in Ayurvedic medicine (the traditional medicine of India). Evidence hints that Tinospora may have anti-cancer (Singh et al., 2005; Singh et al., 2004), immune stimulating (Rawal et al., 2004), anti-diabetic (Stanely et al., 2003; Rathi et al., 2002), cholesterol-lowering (Stanely et al., 2003) and liver-protective (Bishayi et al., 2002) actions. Taking into consideration the medicinal value and utility, the present study has been initiated to evaluate the callus induction and in vitro anti -inflammatory activity in methanolic extracts of in vivo (leaf and stem) and in vitro (callus) plant parts of Tinospora cordifolia.

\section{Materials and Methods}

The explants of stem and leaf of Tinospora cordifolia were collected in Medavakkam, Chennai for callus induction. The explants were washed in the liquid detergent Tween 20 for 3 min and then rinsed in running tap water for 10 min. The cleaned explants were surface sterilized with aqueous $0.1 \%$ mercuric chloride solution for $8 \mathrm{~min}$ followed by 10 rinses in sterile distilled water with one minute intervals. After trimming the cut ends, surface sterilized explants were planted on MS medium supplemented with 2, 4dichlorophenoxy acetic acid (2,4-D) (1.0, 1.25, 1.5 and $2.0 \mathrm{mg} / \mathrm{l})$ along with Benzyl amino purine (BAP) and Kinetin (KIN) $(0.30 \mathrm{mg} / \mathrm{l})$ for callus induction. The cultures were incubated under cool fluorescent lights with 3000 lux for $16 \mathrm{~h}$ at a temperature of $25 \pm 2^{\circ} \mathrm{C}$ and $70 \pm 10$ relative humidity. Each experiment had 10 replicates and repeated at least three times. Data were documented up to seven weeks of culture.
The fresh stem leaves, stem callus and leaf callus of $T$. cordifolia were shade dried and powdered mechanically and stored in an air tight container. The extraction was carried out by hot percolation method using Soxhlet apparatus. The solvent used was ethanol. About $40 \mathrm{gm}$ of powder was extracted with $200 \mathrm{ml}$ of ethanol. The extract was concentrated to dryness under controlled temperature $40-50^{\circ} \mathrm{C}$. The extract was preserved in refrigerator till further use.

The human red blood cell (HRBC) membrane stabilization method (Gandhisan et al., 1991) was used for this study. The blood was collected from healthy human volunteer who was not taken any NSAIDS for 2 weeks prior to the experiment and mixed with equal volume of Alsever solution (2\% dextrose $0.8 \%$ sodium citrate, $0.5 \%$ citric acid and $0.42 \% \mathrm{NaCl}$ ) and centrifuged at 3,000 rpm. The packed cells were washed with isosaline and a $10 \%$ suspension was made. Drug was prepared by 4 gram of stem, leaves, stem callus and leaf callus were macerated with $10 \mathrm{ml}$ of hyposaline $(0.36 \%$ $\mathrm{NaCl}$ ) and extracts is centrifuged at $3000 \mathrm{rpm}$. Various concentrations of drugs were prepared $(25,50$ and $100 \mathrm{~g} / \mathrm{ml})$ using distilled water and to each concentration $1 \mathrm{ml}$ of phosphate buffer, $2 \mathrm{ml}$ hyposaline and $0.5 \mathrm{ml}$ of HRBC suspension were added. Test solution was incubated at $37^{\circ} \mathrm{C}$ for 30 min and centrifuged at 3,000 rpm for $20 \mathrm{~min}$ and the hemoglobin content of the supernatant solution was estimated spectrophotometrically at $560 \mathrm{~nm} 8$. Hydrocortisone was used as reference standard and a control was prepared omitting the extracts.

\section{Results and Discussion}

Stem and leaf pieces were used as a primary explants for callus induction. Callus initiation was observed from cut surface of leaves after 3 to 4 week of culture initiation. The leaf explants responded differently based on the concentrations of auxins and cytokinin present in the medium. In general, media containing high auxin and low cytokinin concentrations promote cell proliferation resulting in callus formation (Slater et al., 2003).Stem explants registered maximum amount of callusing $(74.10 \pm 0.55 \%)$ was observed on the medium supplemented with combination of 2, 4-D and Kin (2.0 mg/1 2, 4-D, 
Int. J. Curr. Res. Med. Sci. (2016). 2(10): 76-81

and $0.3 \mathrm{mg} / \mathrm{l} \mathrm{KIN)}$ after 3 weeks of culture initiation (Table 1 and Fig 1). Minimum response $(41.83+0.32 \%)$ was obtained in leaf explants inoculated at 2,4-D $1.0 \mathrm{mg} / \mathrm{l}$ and BAP $0.30 \mathrm{mg} / \mathrm{l}$ combination (Table 2 and Fig 2). Nakano et al. (1994) found that NAA and 2,4-D alone could initiate callusing from stem, leaf and nodal segments but callus growth was slow. KIN along with auxins considerably enhanced callus growth. Similar to this result, the swelling of explants during the induction of callus was reported in the hypocotyl and leaf explants of Meconopsis simpficifofia (Sulaimanet al., 1991), nodal explants of Dendrocalamus hamiltonii Nees et Arn. Ex Munro (Godbole et al., 2002) and leaf explants of Mentha piperita (L.) (Sujana and Naidu, 2012).
The maximum growth rate in terms of fresh weight $(3.83 \pm 0.53 \mathrm{~g})$ and dry weight $(0.43 \pm$ $0.06 \mathrm{~g}$ ) was observed in the combination of 2, 4-D $1.5 \mathrm{mg} / \mathrm{l}$ and KIN $0.3 \mathrm{mg} / \mathrm{l}$. Minimum growth rate $2.36+0.60 \mathrm{~g}$ fresh weight and $0.23+0.08 \mathrm{~g}$ dry weight was obtained in $1.0 \mathrm{mg} / \mathrm{l} 2,4-\mathrm{D}$ and 0.3 $\mathrm{mg} / \mathrm{l} \mathrm{KIN} \mathrm{combination.} \mathrm{The} \mathrm{induction} \mathrm{of} \mathrm{callus}$ from other members of Menispermaceae viz. Stephania cepharantha Hayata (Suzuki et al., 1992) and Coscinium fenestratum (Nair et al., 1992) were reported when cultured on MS medium supplemented with 2, $4-\mathrm{D}+\mathrm{Kn} / \mathrm{BAP}$. The callus obtained may be maintained on suitable culture condition either to regenerate the plantlets or to produce pharmaceutically important bioactive compounds.

Table 1. Effect of 2,4-D with kin and bap on callus induction, callus growth of young stem explants of Tinospora cordifolia

\begin{tabular}{|c|c|c|c|}
\hline $\begin{array}{c}\text { Hormones } \\
\mathbf{m g} / \mathbf{l}\end{array}$ & $\begin{array}{c}\text { Percentage of } \\
\text { response }\end{array}$ & Fresh weight & Dry weight \\
\hline \multicolumn{4}{|c|}{$\mathbf{2 , 4 - D + K I N}$} \\
\hline $1.00+0.30$ & $63.20 \pm 1.21^{\mathrm{a}}$ & $2.84 \pm 0.29^{\mathrm{a}}$ & $0.27 \pm 0.02^{\mathrm{a}}$ \\
\hline $1.25+0.30$ & $66.20 \pm 0.88^{\mathrm{b}}$ & $3.32 \pm 0.33^{\mathrm{b}}$ & $0.33 \pm 0.04^{\mathrm{b}}$ \\
\hline $1.50+0.30$ & $72.06 \pm 0.67^{\mathrm{d}}$ & $3.92 \pm 0.50^{\mathrm{d}}$ & $0.38 \pm 0.01^{\mathrm{e}}$ \\
\hline $2.00+0.30$ & $60.03 \pm 0.78^{\mathrm{e}}$ & $3.06 \pm 0.18^{\mathrm{c}}$ & $0.31 \pm 0.02^{\mathrm{d}}$ \\
\hline \multicolumn{4}{|c|}{$\mathbf{2 , 4 - D + B A P}^{\mathrm{T}}$} \\
\hline $1.00+0.30$ & $62.10 \pm 1.05^{\mathrm{a}}$ & $2.44 \pm 0.17^{\mathrm{a}}$ & $0.23 \pm 0.04^{\mathrm{a}}$ \\
\hline $1.25+0.30$ & $69.06 \pm 0.67^{\mathrm{c}}$ & $3.11 \pm 0.33^{\mathrm{c}}$ & $0.27 \pm 0.01^{\mathrm{c}}$ \\
\hline $1.50+0.30$ & $71.53 \pm 0.48^{\mathrm{c}}$ & $3.84 \pm 0.29^{\mathrm{d}}$ & $0.31 \pm 0.03^{\mathrm{d}}$ \\
\hline $2.00+0.30$ & $74.10 \pm 0.55^{\mathrm{d}}$ & $4.03 \pm 0.15^{\mathrm{e}}$ & $0.36 \pm 0.02^{\mathrm{e}}$ \\
\hline
\end{tabular}

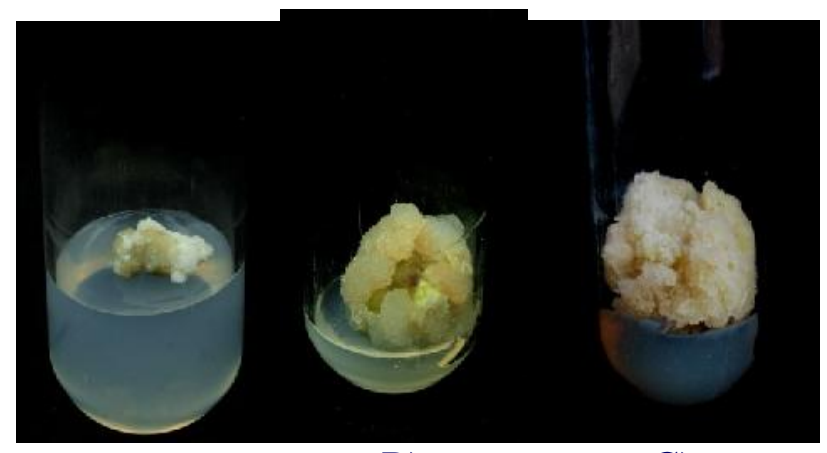

A)

B)

C)

Fig - 1: In vitro callus induction from leaf explant of-Stage wise development in 2, 4-D + KIN concentration

A) Callus induction in earlier stage, B \& C) Matured callus 
Int. J. Curr. Res. Med. Sci. (2016). 2(10): 76-81

Table 2: Effect of 2,4-D with kin and bap on callus induction, callus growth of young leaf explants of Tinospora cordifolia

\begin{tabular}{|c|c|c|c|}
\hline $\begin{array}{c}\text { Hormones } \\
\mathbf{m g} / \mathbf{l}\end{array}$ & $\begin{array}{c}\text { Percentage of } \\
\text { response }\end{array}$ & Fresh weight & Dry weight \\
\hline \multicolumn{4}{|c|}{$\mathbf{2 , - D + K I N}$} \\
\hline $1.00+0.30$ & $51.15 \pm 0.83$ & $2.93 \pm 0.53$ & $0.30 \pm 0.07$ \\
\hline $1.25+0.30$ & $67.63 \pm 0.65$ & $3.80 \pm 0.36$ & $0.36 \pm 0.02$ \\
\hline $1.50+0.30$ & $70.82 \pm 0.36$ & $3.83 \pm 0.53$ & $0.43 \pm 0.06$ \\
\hline $2.00+0.30$ & $65.83 \pm 0.368$ & $3.10 \pm 0.16$ & $0.33 \pm 0.01$ \\
\hline \multicolumn{4}{|c|}{$\mathbf{2 , 4 - D + B A P}$} \\
\hline $1.00+0.30$ & $41.83 \pm 0.32$ & $2.36 \pm 0.60$ & $0.23 \pm 0.08$ \\
\hline $1.25+0.30$ & $64.25 \pm 0.32$ & $3.18 \pm 1.93$ & $0.30 \pm 0.03$ \\
\hline $1.50+0.30$ & $69.86 \pm 0.53$ & $3.66 \pm 1.63$ & $0.34 \pm 0.03$ \\
\hline $2.00+0.30$ & $58.30 \pm 0.65$ & $2.74 \pm 0.83$ & $0.24 \pm 0.06$ \\
\hline
\end{tabular}

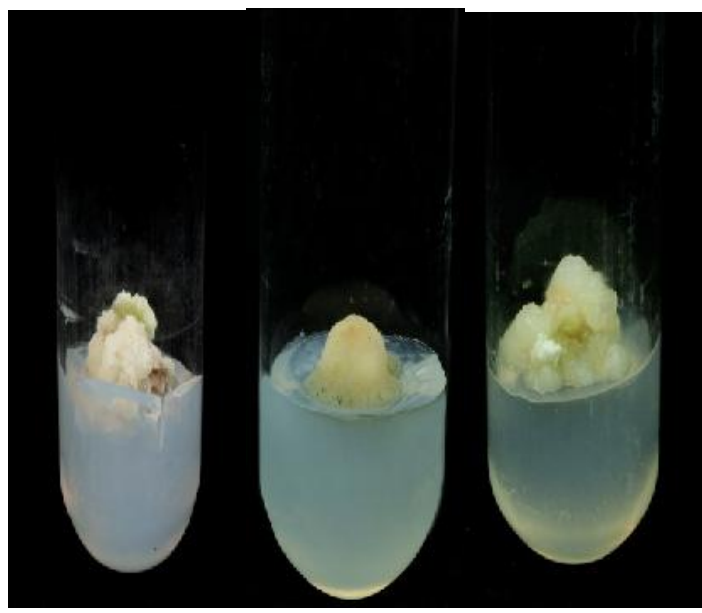

A) B)

C)

Fig - 1: In v itro callus induction from leaf explant of-Stage wise development in 2, 4-D + KIN concentration

A) Callus induction in earlier stage,B \& C) Matured callus

The extracts of the stem, leaves, stem callus and leaf callus of $T$. cordifolia were studied for in vitro anti-inflammatory activity by HRBC membrane stabilization method. Among all the extracts showed significant anti-inflammatory activity in a concentration dependent manner. Leaf callus extract at a concentration of $100 \mathrm{~g} / \mathrm{ml}$ showed $78.15 \pm 1.13 \%$ protection of $\mathrm{HRBC}$ in hypotonic solution. All the results were compared with standard hydrocortisone which showed $80 \%$ protection (Table 2). The extracts exhibited membrane stabilization effect by inhibiting hypotonicity induced lyses of erythrocyte membrane. The erythrocyte membrane is analogous to the lysosomal membrane (Chou,
1997) and its stabilization implies that the extract may as well stabilize lysosomal membranes. Stabilization of lysosomal membrane is important in limiting the inflammatory response by preventing the release of lysosomal constituents of activated neutrophil such as bactericidal enzymes and proteases, which cause further tissue inflammation and damage upon extra cellular release (Murugasan et al., 1981). Some of the NSAIDs are known to possess membrane stabilization properties which may contribute to the potency of their anti-inflammatory effect. Though the exact mechanism of the membrane stabilization by the extract is not known yet, hypotonicity-induced hemolysis may arise from 
Int. J. Curr. Res. Med. Sci. (2016). 2(10): 76-81

shrinkage of the cells due to osmotic loss of intracellular electrolyte and fluid components. The extract may inhibit the processes, which may stimulate or enhance the efflux of these intracellular components (Iwueke et al., 2006).

The present in-vitro study is a preliminary evaluation of anti-inflammatory activity of native and callus extracts of Tinospora cordifolia and demonstrated that folk medicine of these plants can be used to cure the inflammation. Further research work to analyze in-vivo antiinflammatory activity of these two plants on animal models and to isolate the phytoconstituents responsible for antiinflammatory activity are ongoing.

\section{References}

Bishayi, B., Roychowdhury, S and Ghosh, S. 2002. Hepatoprotective and immunomodulatory properties of Tinospora cordifolia in $\mathrm{CCl} 4$ intoxicated mature albino rats. J. Toxicol. Sci. 27: 139-46.

Chou, CT. 1997. The anti-inflammatory effect of Tripterygium wilfordii Hook $\mathrm{F}$ on adjuvantinduced paw edema in rats and inflammatory mediators release. Phytother Res., 11: 152-54.

David wilson, Vijaya, PP., Yogananth, N and Syed ali. 2014. . In vitro screening for antiinflammatory activity of Basella alba and Alternanthera sesssilis - impartent edible green leaves. International Journal of comprehensive Research in Biological Sciences. 1(1): 9-1227-30.

Gandhisan, R., Thamaraichelvan, A. and Baburaj, C. 1991. Anti-inflammatory action of Lannea coromandelica HRBC membrane stabilization. Fitoterapia. 62: 81-83.

Godbole, S., Sood, A., Thakur, R., Sharma, M and Ahuja, PS. 2002. Somatic embryogenesis and its conversion into plantlets in a multipurpose bamboo, Dendrocalamus hamiltonii Nees et Arn. Ex Munro. Cur Sci. 83: 885-889.

Iwueke, AV., Nwodo, OF and Okoli,CO. 2006. Evaluation of the anti inflammatory and analgesic activities of Vitex doinana leaves. African J Biotech., 5: 1929-35.
Murugasan, N., Vember, S. and Damodharan,C. 1981. Studies on erythrocyte membrane IV: In vitro hemolytic activity of oleander extract. Toxicol Lett.. 8: 33-38.

Nair, AJ., Sudhakaran, PR., Rao, JM and Ramakrishna, SV. 1992. Berberine synthesis by callus and cell suspension cultures of Coscinium fenestratum. Plant Cell Tissue Organ Cult. 29: 7-10.

Nakano, M., Hoshino, Y and Mii, M. 1994. Adventitious shoot regeneration from cultured petal explants of Carnation. Plant Cell Tissue and Organ Culture. 36, 15-19.

Rathi, SS., Grover, JK and Vikrant, V. 2002. Prevention of experimental diabetic cataract by Indian ayurvedic plant extracts. Phytother. Res. 16:774-7.

Rawal, AK., Muddeshwar MG and Biswas, SK. 2004. Rubia cordifolia, Fagonia cretica Linn and Tinospora cordifolia exert neuroprotection by modulating the antioxidant system in rat hippocampal slices subjected to oxygen glucose deprivation. BMC Compl. Altern. Med. $4: 11$.

Singh, N, Singh, SM and Shrivastava, P. 2004. Immunomodulatory and antitumor actions of medicinal plant Tinospora cordifolia are mediated through activation of tumorassociated macrophages. Immunopharmacol Immunotoxicol. 26: 145-62.

Singh, N., Singh, SM and Shrivastava, P. 2005. Effect of Tinospora cordifolia on the antitumor activity of tumor-associated macrophagesderived dendritic cells. Immunopharmacol Immunotoxicol. 27: 1-14.

Slater, A., Scotee, N and Wand-Fowler, MR. 2003. Plant Biotechnology (The Genetic Manipulation of Plants). Oxford University Press.

Sosa, S., Balicet, MJ., Arvigo, R., Esposito, RG., Pizza, C and Altinier, GA. 2002. Screening of the topical anti-inflammatory activity of some central American plants. J Ethanopharmacol,8: 211-215.

Stanely Mainzen Prince, P and Menon, VP. 2003. Hypoglycaemic and hypolipidaemic action of alcohol extract of Tinospora cordifolia roots in chemical induced diabetes in rats. Phytother. Res. 17: 410-3. 
Int. J. Curr. Res. Med. Sci. (2016). 2(10): 76-81

Sujana, P and Naidu, CV. 2011. Indirect Plant Regeneration from Leaf Explants of Mentha piperita (L.) - An Important Multipurpose Medicinal Plant. Journal of Phytology. 3: 1922.

Sulaiman IM., Rangaswamy NS and Babu CR. 1991. Formation of plantlets through somatic embryogeny in Himalayan blue poppy, Meconopsis simpficifofia (Papaveraceae). Plant Cell reports. 1991; 9: 582-585

Suzuki, S., Fujino, H., Tatsuo, Y., Yamazaki, N and Yoshizaki, M. 1992. Rapid propagation of

Stephania cephalantha Hayata by tissue culture. Japan J Breed. 42: 769-777

Whitehouse, M.W. 1974. In: Introduction and Background to the Regulation of Inflammation and the Immune Response. Vol. 2, p12. Academic Press, New York, NY.

Yogananth, N.,Palanivel, S., Parvathy, S., Chanthuru, A. and Bhakyaraj, R. 2012.Effect of different plant hormones on callus induction in Leaf explant of Dregea volubilis Benth. (Asclepiadaceae). Journal bioscience Research. 3(3):198-202.

\begin{tabular}{|c|l|}
\hline \multicolumn{2}{|c|}{ Access this Article in Online } \\
\hline & Website: \\
\hline & www.ijcrims.com \\
\hline Quick Response Code & Subject: \\
Medicinal Plants
\end{tabular}

How to cite this article:

Maanhvizhi. E and Revathi. K. (2016). In vitro anti-inflammatory activity and tissue culture studies on Tinospora cordifolia. Int. J. Curr. Res. Med. Sci. 2(10): 76-81.

DOI: http://dx.doi.org/10.22192/ijcrms.2016.02.10.008 